Stanisław Borsza: Cara moskiewskiego wyprawa naonczas do Moskwy z panem wojewodą sendomirskim i z inszym rycerstwem Anno Domini 1604

Janusz Byliński 


\section{Stanisław Borsza}

\section{Cara moskiewskiego wyprawa naonczas do Moskwy z panem wojewodą sendomirskim i z inszym rycerstwem Anno Domini 1604}

\section{Opracował i wstępem poprzedził Janusz Byliński}

$\mathrm{O}$ ddając do druku niepublikowany dotąd w Polsce pamiętnik rotmistrza Stanisława Borszy z czasów Dymitra I Samozwańca, należy krótko zaznajomić Czytelnika z tłem historycznym pamiętnika, które pozwoli usytuować przedstawiane w nim wydarzenia w nieco szerszym kontekście, a przede wszystkim określić w nich udział Polaków ${ }^{1}$. Osobie Dymitra i wojewodzianki sandomierskiej Maryny Mniszchówny poświęcono już kilka odrębnych monografii, więc nie ma powodu, by się nimi tu szerzej zajmować. Ograniczymy się zatem do kilku niezbędnych uwag, uzupełniających obraz tych niezwykłych wydarzeń o niemal baśniowym charakterze.

Umierając w 1584 roku, car Iwan IV Groźny pozostawił po sobie dwóch synów: chorowitego, „słabego na umyśle” Fiodora i małoletniego Dymitra. W trosce o swych potomków i zapewnienie ładu w państwie Iwan wyznaczył czterech regentów spośród znaczniejszych bojarów: Nikitę Romanowa-Juriewa, Iwana Mścisławskiego, Iwana Szujskiego i Bogdana Bielskiego ${ }^{2}$. Jednakże zaraz po śmierci Groźnego doszło do ostrej rywalizacji regentów o władzę. Sukces w tej walce przypadł nieoczekiwanie ulubieńcowi cara, pochodzącemu ze skromnego rodu postelniczemu (odpowiednik szambelana), świeżo kreowanemu bojarem Borysowi Godunowowi, którego sio-

\footnotetext{
1 W dzieje „smuty” moskicwskiej i „Dymitriady” wprowadza nas najlepiej praca Alcksandra Hirschberga, Dymitr Samozwaniec, Lwów 1898, w którcj pojawia sic̨ dość często rotmistrz Borsza, ponadto nowsza monografia Danuty Czerskiej, Dymitr Samozwaniec, Wrocław 1995 i Rusłana Skrynnikowa, Borys Godunow, Warszawa 1982. Stosunki polsko-moskicwskie omawia praca Jaremy Maciszewskiego, Polska a Moskwa 1603-1618, Warszawa 1968. Pomijam tu starsze prace historyków rosyjskich.

2 Zob. R. Skrynnikow, op. cit., s. 20.
} 
stra Irina została wydana za następcę tronu, carewicza Fiodora. Małzeństwo to okazało się bezdzietne, co zrodziło problem sukcesji po Fiodorze, zwłaszcza gdy 15 maja 1591 roku zmarł w niewyjaśnionych okolicznościach carewicz Dymitr, zesłany wraz z matką Marią Nagoj do oddalonego od Moskwy Uglicza. Carewicz, w trakcie zabawy, miał ugodzić się śmiertelnie nożem, lecz opozycja wiązała jego śmierć z zabójstwem na zlecenie Godunowa. Najgroźniejsi konkurenci Borysa, wywodzący się ze starych rodów bojarskich, spokrewnieni z Rurykowiczami, uważali się za bardziej uprawnionych do objęcia władzy w państwie moskiewskim i nie zaniechali spisków przeciw uzurpatorowi. Ten jednakże, po śmierci Fiodora w 1598 roku, dzięki zręcznym manewrom rozgromił swych rywali i po odegraniu rytualnego spektaklu, niby broniąc się przed objęciem tronu, dał się w końcu „uprosić” i przyjął ofiarowaną mu przez Sobór Ziemski koronę carską (czapkę Monomacha). Ale sytuacja nowo kreowanego cara okazała się nadzwyczaj trudna. Po rządach opryczniny w czasach Iwana Groźnego, po klęskach wojennych w zmaganiach z Batorym i sprzymierzoną z nim Szwecją, państwo moskiewskie nawiedził głód i wywołane nim bunty ludności. Już przed koronacją Borysa zrodziła się w kręgach Romanowów pogłoska o cudownym ocaleniu od śmierci carewicza Dymitra, która potem przycichła, ale odżyła ponownie, gdy Borys ciężko zachorował i wydawało się, że walka o tron odżyje na nowo ${ }^{3}$. Gdy Borys wyzdrowiał, represje dotknęły najbardziej Romanowów i ich służbę, i sprawiły, że jeden spośród ich sług Jurij (Juszka) Otrepiew, syn Bogdana, ubogiego szlachcica, znalazł się w kręgu podejrzanych. Uchodząc przed ewentualnymi represjami, schronił się w jednym z klasztorów, gdzie jako czerniec (mnich) mógł czuć się bezpiecznie. Tam szybko doceniono jego dużą inteligencję i ładny charakter pisma. W krótkim czasie trafił więc na dwór patriarchy moskiewskiego Hioba, gdzie cieszył się dużym uznaniem, komponując pieśni religijne. Czy tam przygotowano go do odegrania roli carewicza, trudno dociec. W każdym razie w 1602 roku rozeszła się wieść w państwie moskiewskim o pojawieniu się w Polsce człowieka podającego się za carewicza Dymitra. Władze carskie ogłosiły, iż pod tym imieniem kryje się zbiegły z monasteru Czudnowskiego czerniec Griszka (Grzegorz) Otrepiew ${ }^{4}$. W tym czasie rzeczywiście trzech mnichów przekroczyło granicę polsko-moskiewską, udając się najpierw do Kijowa, a stamtąd do Ostroga, posiadłości kniazia Konstantego Ostrogskiego. Zbiegów przyjął na swój dwór w Hoszczy, sąsiadujący z Ostrogiem, znany arianin Gabriel Hojski, gdzie ów przybysz w trakcie długich dyskusji z tamtejszymi teologami zapoznał się z doktryną ariańską i przesiąkł jej wpływem.

Po opuszczeniu Ostroga i Hoszczy mnich Grzegorz zjawił się u kniazia Adama Wiśniowieckiego i tam przypuszczalnie nawiązał kontakty z Kozakami. Ponadto, w czasie udawanej czy prawdziwej choroby, miał ujawnić Wiśniowieckiemu swoje „prawdziwe” pochodzenie, podając świadków i dowody „cudownego” ocalenia z rąk siepaczy Godunowa. Z kolei Wiśniowiecki przekazał już teraz „carewicza” Dymitra Stadnickim i Mniszchom. Dla wojewody sandomierskiego Jerzego Mniszcha, zadłużonego po uszy u króla, był to przysłowiowy uśmiech fortuny. Zajął się więc

\footnotetext{
${ }^{3}$ Zob. ibidem, s. 31, 33-35 in.

${ }^{4}$ Wg A. Hịrschberga (op. cit., s. 24) Samozwanicc miał się ukrywać przez jakiś czas na dworze kniazia Mścisławskiego.
} 
skwapliwie młodzieńcem i zaczął szukać dlań możnych protektorów. „Carewicz” zaś zakochał się w pięknej córce wojewody i poprosił ojca o jej rękę. Wojewoda zgodził się przyjać oświadczyny, ale dopiero po odzyskaniu tronu przez pretendenta do ręki wojewodzianki. Dymitr przyjął ten warunek i zobowiązał się wynagrodzić wojewodę znaczną sumą pieniędzy, a swą przyszłą żonę Marynę uczynić carową moskiewską. Był to początek wielkiej intrygi, która miała wynieść córkę wojewody na tron moskiewski, a rodzinie Mniszchów i ich krewnym zapewnić świetne apanaże. Tak więc Jerzy Mniszech wraz z „carewiczem” Dymitrem udał się do Krakowa, gdzie spotykal się z tamtejszymi jezuitami i odbywał z nimi długie dysputy teologiczne, w czasie których młodzieniec wykazał duże zainteresowanie dla ich argumentacji. W wyniku tych spotkań, po dluższym namyśle, Dymitr miał podobno potajemnie przejść na obrządek rzymski i zezwolić na jego propagowanie w Moskwie, gdy tylko zdobędzie władzę. O swym „cudownym” ocaleniu napisał list do papieża, prosząc o opiekę. Dzięki tym posunięciom Dymitr zyskał sobie możnego protektora w osobie gorliwego katolika, wojewody krakowskiego Mikołaja Zebrzydowskiego, późniejszego przywódcy rokoszu z lat 1606-1609. Tak więc sprawa Dymitra zatoczyła szerokie kręgi i dotarła na dwór królewski. Zygmunt III odniósł się do tej rewelacji dość sceptycznie, lecz z czasem udzielił Samozwańcowi skromnego poparcia, naruszając tym obowiązujący rozejm z Moskwą. Dymitr zaś obiecał królowi pomoc w odzyskaniu dziedzicznego królestwa szwedzkiego, zyskując dzięki temu możliwość zwerbowania skromnych oddziałów zaciężnych w Polsce, a jego protektorom, Mniszchom, zaangażowanie się w tę imprezę za cichym przyzwoleniem królewskim ${ }^{5}$. Tak więc w początkach stycznia 1604 roku odbył się werbunek ochotników do wyprawy moskiewskiej. Miejscem koncentracji stały się należące do kniazia Michała Wiśniowieckiego Łubnie, położone nad rzeką Sułą na pograniczu moskiewskim ${ }^{6}$. Ochotnikami byli głównie Kozacy naddnieprzańscy i dońscy, werbowani już wcześniej. Tymczasem Dymitr, przebywający jeszcze w Krakowie, wraz z Jerzym Mniszchem czynil przygotowania do wymarszu ku granicy moskiewskiej. 15 marca przybył na Wawel i został przyjęty na audiencję u króla, którego prosił o łaskawość i pomoc w odzyskaniu dziedzictwa, obiecując odwdzięczyć się po odzyskaniu tronu. Do Krakowa przybyli posłowie od Kozaków dońskich z ofertą zaciągnięcia się na służbę u Dymitra, a także przyjechało „kilkunastu synów bojarskich”. Rozpoznali oni w Dymitrze „prawdziwego" carewicza Dymitra i oddali mu cześć. Wszystko to świadczy o tym, że intryga przygotowana była dużo wcześniej i uczestniczyli w niej bojarzy, przeciwnicy Godunowa. 23 kwietnia odbył Dymitr audiencję pożegnalną u króla, otrzymał od Zygmunta III złoty łańcuch i 4 tys. złotych, zaś nuncjusz papieski Klaudiusz Rangoni ofiarował mu medalik i 25 dukatów. Dymitr natomiast przekazał nuncjuszowi ów słynny list do papieża Klemensa VIII ${ }^{7}$.

Z Krakowa Samozwaniec udał się wraz z Jerzym Mniszchem do Sambora, posiadłości Mniszchów, gdzie 25 maja 1604 roku wystawił dokument z licznymi zobowiązaniami dla wojewody, jego córki

5 Zob. D. Czerska, op. cit., s. 26-28.

6 Zob. ibidem, s. 33; A. Hirschberg, op. cit., s. 25. Eubnic (lub Łubny) otrzymał kniaź M. Wiśniowiecki po bracie Alcksandrzc - zob. J. Wolff, Kniaziowie litewsko-ruscy, Warszawa 1895, s. 561.

7 Zob. D. Czerska, op. cit., s. 43. 
i braci. Przez cały czas trwały przygotowania do wymarszu, aż wreszcie 25 sierpnia Dymitr wraz z wojewodą sandomierskim wyruszył z Sambora, najpierw do Lwowa, gdzie 29 tego miesiąca uczestniczył w nabożeństwie katolickim i wysłuchał kazania jezuity, przełożonego miejscowego kolegium, a 7 września wyruszył do położonych na wschód od Lwowa Glinian. Tam dokonal przeglądu swego wojska liczącego około 4500 ludzi, w tym blisko 2000 Kozaków $^{8}$. Z tą garstką zbieraniny Dymitr Samozwaniec zamierzał wyruszyć na podbój Moskwy, „utraconego dziedzictwa”.

W tym miejscu rozpoczyna się pamiętnik rotmistrza Stanisława Borszy, „dworzanina wielkiego cara moskiewskiego Dymitra Iwanowicza", prowadzony do 4 marca 1606 roku. W niespełna trzy tygodnie później rotmistrz Borsza, broniąc się do upadłego przed nacierającym tłumem, zginął na ulicach Moskwy wraz z kilkoma swymi sługami ${ }^{9}$.

Dzieje „Dymitriady” są dobrze znane, o czym była mowa wyżej, więc tylko skrótowo zapoznajmy się z jej epilogiem. Już pierwsze wielkie zwycięstwo Dymitra pod Nowogrodem Siewierskim świadczyło o istniejącym sprzysiężeniu przeciw carowi Borysowi. Nawet opuszczenie Dymitra przez wojewodę sandomierskiego i znaczną część oddziałów polskich nie przekreśliło jego kariery, mimo załamania psychicznego po klęsce pod Dobryniczami. Jakieś tajemne siły sprawiły, że odnosił dalsze zwycięstwa, a kiedy zaczął zbliżać się do stolicy moskiewskiej, zmarł nagle Borys Godunow, zaś Moskwa po pewnych wahaniach otworzyła mu swe bramy i uznała za przyrodzonego pana. Ale już wówczas bojarowie Szujscy zaczęli publicznie rozgłaszać, że Dymitr jest szalbierzem, a prawdziwy carewicz od dawna nie żyje. Wprawdzie Szujscy powędrowali za to do więzienia i groziła im kara śmierci, lecz Dymitr okazał się wspaniałomyślny i ułaskawił ich, karząc jedynie zesłaniem, które szybko zostało odwołane, a Szujscy przywróceni do łask. Dymitr zdołał się koronować, miał czas, ażeby poprosić króla Zygmunta III o zgodę na poślubienie Maryny, zawrzeć z nią ślub per procura w Krakowie, sprowadzić ją wraz z licznym orszakiem na wesele do Moskwy i koronować na carową moskiewską, co stanowiło szczyt jego błyskotliwej kariery. Ale już w trakcie uroczystości weselnych 27 maja, w wyniku spisku tychże Szujskich, doszło do zabójstwa Dymitra i rzezi przebywających tam Polaków, z której uszedł szczęśliwie wraz z córką, carową Maryną, wojewoda sandomierski Jerzy Mniszech. Sprawca zamachu, kniaź Wasyl Szujski zasiadł niebawem na tronie carskim, ale utrzymał się na nim jedynie do następnego zamachu w 1610 roku, kiedy to rada bojarska powołała syna Zygmunta III, królewicza Władysława. Było to jednak tylko krótkie interludium, po którym Sobór Ziemski powołał w początkach 1613 roku na tron Michała Romanowa, syna przebywającego w Polsce metropolity Filareta, postrzyżonego niegdyś na mnicha Fiodora Romanowa, czwartego z regentów ustanowionych przez Iwana Groźnego, który po wyeliminowaniu z gry trzech rywali zdobył tron moskiewski dla swego syna, założyciela dynastii Romanowów, panujących w ciągu 300 lat w Rosji, aż do Rewolucji Październikowej.

Pamiętnik Stanisława Borszy stanowi pierwszorzędne i wiarygodne źródło historyczne i wykorzystywany był zarówno przez historyków polskich, jak i rosyjskich, zajmujących się „Dymi-

8 Zob. ibidem, s. 55; A. Hirschberg, op. cit., s. 69-71.

9 Zob. Pamiętniki Samuela i Bogustawa Kazimierza Maskiewiczów (wiek XVII), opr. A. Sajkowski, Wrocław 1961, s. 23, 96. 
triadą" oraz smutą moskiewską. Mikołaj Kojałowicz przedrukował go z rękopisu w petersburskim wydawnictwie Russkaja Istoriczeskaja Biblioteka w tłumaczeniu rosyjskim z równoległym tekstem polskim $^{10}$. O samym autorze pamiętnika brak pewnych informacji. Zarówno Niesiecki, jak i Boniecki czy Uruski wymieniają Borszów (Borsów) zamieszkałych w województwie łęczyckim, płockim, rawskim i lubelskim. Jedni pieczętowali się herbem Dołęga, inni Nałęcz. Niesiecki (t. II, s. 251-252) wymienia Borszów w województwie łęczyckim, z których mógł pochodzić nasz pamiętnikarz, podobnie Uruski (Rodzina, t. I, s. 343), lecz są to tylko przypuszczenia nie poparte źródłami. Tragiczna śmierć rotmistrza Borszy została odnotowana w licznych relacjach z tych wydarzeń $^{11}$. W jednej z parafraz w tomie Horatius Flaccus $w$ trudach więzienia moskiewskiego wspominał go Sebastian Petrycy:

Nie masz cię, Janie z Żywca, Balu, Gołuchowski, Śpisz Szkliński, Domaradzki, Borsza i Strzeżowski!

Ale kto może pobitych żelazem

Wymienić wszystkich bez żałości razem? ${ }^{12}$

Rotmistrz Stanisław Borsza wystąpił też na kartach powieści historycznej Andrzeja Stojowskiego Carskie wrota (Warszawa 1981, s. 83, 94, 227, 304, 329), gdzie jego rola została wiernie odtworzona na podstawie źródeł historycznych, i w ślad za Aleksandrem Hirschbergiem dowiadujemy się, że po odprowadzeniu Dymitra do Moskwy rotmistrz Borsza, udając się do kraju, spotkał w Smoleńsku niejakiego Chrypunowa, prawdopodobnie jednego z agitatorów wysłanych przez Szujskich, od którego usłyszał o dojrzewającym w Moskwie spisku. Ostrzeżenie to przekazał Borsza zaufanemu sekretarzowi Dymitra, Janowi Buczyńskiemu, lecz zostało ono zlekceważone i na skutek tego po powrocie do Moskwy Borsza znalazł bohaterską śmierć na jej ulicach ${ }^{13}$.

Podstawę wydawniczą niniejszego pamiętnika stanowi rękopis Biblioteki Jagiellońskiej BJ 102 III, s. 282-292, skonfrontowany z odpisem Zygmunta Stefana Koniecpolskiego w rękopisie Biblioteki Kórnickiej PAN 201 (k. 108 r.-114 r., dalej: BK) oraz wydawnictwem petersburskim (dalej: $R I B$; uzupełnienia za tym źródłem ujęto w klamry: \{\} ). Wszystkie oboczności zostały zaznaczone w przypisach tekstowych. Dwa dołączone aneksy ze zbiorów Biblioteki Ossolineum we Wrocławiu i Biblioteki Czartoryskich w Krakowie stanowią niezbędne uzupełnienie pamiętnika Borszy. Całość została opracowana zgodnie z ogólnie przyjętymi zasadami edycji źródeł staropolskich,

10 Zob. S. Borsza, Wyprawa cara moskiewskiego Dymitra do Moskuy z Gerzim Mnischem, wojewodq sandomierskim i z inszym rycerstwem Roku 1604, w: Russkaja Istoriczeskaja Biblioteka, t. 1, Petersburg 1872, s. $366-426$ (tekst polski do s. 401).

11 Zob. m.in.: Pamiętnik Stanisława Niemojewskiego (1606-1608), wyd. A. Hirschberg, Lwów 1899, s. 92; Diariusz Wacława Dyamentowskiego (1605-1609) [właśc. Abrahama Rożniatowskicgo], w: Polska a Moskwa w' pienvszej polowie XVII wiekw, wyd. A. Hirschberg, Lwów 1901, s. 56; ponadto: Poselstwo od Zygmunta III do Dymitra Iu'anowicza, cara moskiewskiego, wyd. E. Raczyński, Wrocław 1837, s. 93.

i2 S. Pctrycy, Horatius Flaccus w trudach więzienia moskienuskiego 1609, wyd. J. Łoś, Kraków 1914 (BPP 67), s. 57: Oda XXIIII. Do Jego Mości Pana Mikotaja Komorouskiego starosty ośuiecimskiego etc. [parafraza c. I 24, Quis desiderio sit pudor aut modus Horaccgo], w. 13-16, cyt. A. Sajkowski we wstępie do Pamiętnika S. Maskicwicza, op. cit., s. 23.

13 Zob. A. Hirschberg Dymitr Samozwaniec, op. cit., s. 183; Polska a Moskwa..., op. cit., s. 56. 
odnoszącymi się do dzieł popularnonaukowych. A zatem zmodernizowana została pisownia $\mathrm{i}$ interpunkcja przy zachowaniu osobliwości językowych. Ujednolicone zostały skróty i zachowana pisownia form grzecznościowych typu JM (Jegomość), WM (Waszmość), JKM (Jego Królewska Mość). Nazwiska osób występujących w pamiętniku i trudniejsze wyrazy zostały objaśnione w przypisach.

Trudu zestawienia trzech wersji pamiętnika podjęła się pani mgr Bożena Górna, za co składam Jej gorące podziękowanie.

Jamusz Bylinski 
Taprzód popis wojska pod Gliniany ${ }^{1}$, gdzie rycerstwo zjechawszy się, uczynili koło i obrali 1 między sobą hetmana JM pana wojewodę sędomirskiego, a pułkowniki, jednego pana Żulickiego Adama ${ }^{2}$, drugiego pana Adama Dworzyckiego ${ }^{3}$, uchwaliwszy artykuły w kole. Ruszyły się z carowiczem roty trzy: jedna pana starosty sanockiego ${ }^{4}$, druga pana Fredrowa ${ }^{5}$, trzecia carska. A piechoty 400. A insze roty poszły w bok i pozad, i nie zeszły się do kupy, aż nad Dnieprem dwie mili za Kijowem ku Ostrzu ${ }^{6}$, ku granicy moskiewskiej. Idąc ku Kijowu, obawialiśmy się wojska pana krakowskiego ${ }^{7}$, którego było kilka tysięcy, które się wieszało nad nami aż do samego Dniepru, dlaczegośmy byli ostrożni, nie sypiając po samej nocy i konie gotowe mając.

Przyszliśmy potym nad Dniepr, gdzie pan krakowski wszystkie promy kazał pozaciągać przecz. I dlategośmy się kielka dni zatrzymali nad Dnieprem, póki nam nie przyszły promy, i z łaski Bożej przewieźliśmy się przez Dniepr bez szkody. Telko jeden towarzysz, mając się czas długi febrą i gorączkę, umyślnie wyskoczyl z promu w wodę, utęskniwszy sobie w chorobie, i utonął.

Przeprawiwszy się przez Dniepr, poszliśmy dąbrowami i polmi barzo wesołemi ${ }^{8}$, trawami barzo wielkiemi i pogodami ${ }^{9}$ \{wdzięcznemi\}, zasiągając i żywności po trosze. Minąwszy tedy Ostrz $^{10}$, zamek ukrainny króla, pana naszego, pod Morawsk ${ }^{11}$, zamek moskiewski, będąc od niego w piąci mili, zgodziwszy się jednostajnie rycerstwo z panem hetmanem, wyprawili przed sobą kilka pułków kozackich, mianowicie Bieliaszka ${ }^{12}$, który miał Kozaków ukrainnych 2000 , Kucka drugiego i Szwajkowskiego ${ }^{13}$. Dowiedziawszy się Moskwa ${ }^{14}$ na Morawsku, iż idzie car w ziemie z wojskiem polskiem, poczęli z sobą trwożyć i radzić, dlatego więcej z bojaźni niż z dobrej wolej wyprawili posły swe do cara, poddając się carowi. I przyszliśmy z wojskiem w sprawie pod tenże zamek Morawsk i położyliśmy się obozem. A car z panem wojewodą wjachał do zamku i ten zamek odebrał, i z armatą i Moskwą zarazem oddali posłuszeństwo z przysięgą.

Opatrzywszy tedy zamek, ruszyliśmy się pod Czernieow ${ }^{15}$, mil $12^{16}$ od Morawska, nad tąż rzeką ${ }^{17}$ Desną $^{18}$ leżący, nad którą i Morawsk. Ten Czernieow zamek barzo mocny i miasto dobrze

1 Gliniany - miasteczko położone $28 \mathrm{~km}$ na wschód od Lwowa, znane z rokoszu w 1537 roku.

2 Adam Zulicki, pułkownik wojsk Dymitra Samozwańca; pochodził zapewne z rodziny herbu Janina, osiadłcj w województwic ruskim.

3 Adam Dworzycki, rotmistrz, późnicj pułkownik i hetman w wojsku Dymitra; pochodził z tegoż województwa ruskiego, wsławiony późnicj odwagą i męstwem w bitwic pod Nowogrodem Sicwicrskim, po rewolcic Szujskich w nicwoli moskicwskicj.

4 Stanisław Mniszech, syn wojcwody sandomicrskicgo Jcrzego, brat carowcj Maryny.

${ }_{6}^{5}$ Jan Fredro, syn Jana, kasztelana przemyskiego, herbu Bończa.

${ }^{6}$ Ostrze - miasteczko i starostwo grodowe w pobliżu Kijowa; starostą osterskim i bobrownickim był Michał Ratomski.

7 Janusz Ostrogski, książe (ok. 1554-1629), wojewoda wołyński, od 25 lutcgo 1593 roku kasztclan krakowski, picrwszy senator świecki w hicrarchii urzędów Rzeczypospolitcj.

wesolymi - żyznymi.

${ }_{9}$ RIB: jagodami; BK: pogodami.

${ }_{11}^{10}$ RIB: Orszą [sic!]; BK: Ostrog.

11 Morawsk (w rękopisach także: Morawisk), gród moskicwski, tuż nad granicą Rzeczypospolitej na północny wschód od Kijowa.

12 Bicliaszka lub Bcliszka - pulkownik kozacki.

13 Kucka lub Kącki (RIB: Szwajkowski) — dowódcy rot kozackich.

${ }_{15}$ W XVII wicku mówiono i pisano zazwyczaj „Moskwa” na oznaczenie narodu, kraju, państwa i stołecznego miasta.

${ }^{15}$ Czernicjow, Czcrnichów - miasto obwodowe w północnej części Ukrainy na prawym brzegu Desny, dopływ Dniepru.

${ }^{16}$ RIB: 18 mil.

17 BK: Dembnam.

18 Desna - dopływ Dniestru. 
armatą opatrzone. Kozacy, przyszed[ł] szy przed wojskiem pod Czernieow, podjeżdżali pod zamek i pod miasto, wołając, aby się poddali carowi Dymitru Iwanowiczu, panu swemu przyrodzonemu. Oni na to nic nie dbając, owszem strzelali na Kozaki i siła ich pobili. Jednak dowiedziawszy się czarniechowcy, iż się Morawsk poddał, weszli z sobą w radę i niektórzy z nich pozwalali, aby się poddać carowiczowi, telko był naprzeciwko temu jeden wojewoda, kniaź Iwan, którego Moskwa związali. A interim Kozacy puścili do szturmu do miasta i ubiegli miasto, chcąc się łupem zbogacić, póki by ${ }^{19}$ wojsko nie przyszło. I tak Moskwa dała znać z Czernieowa, prosząc go, aby posłał do Kozaków, żeby miasta nie plundrowano ${ }^{20}$, gdyż się dobrowolnie poddajemy. Będąc car stąd żałosny, z wojskiem swym wyprawił do Kozaków pana Stanisława Borszę z panem Przeradowskiem $^{21}$, dworzanów i żołnierzów swej roty. I nim posłowie ci mianowani przybieżeli, tym Kozacy miasto splondrowali, złupili, tylko krobie stały próżne nad jamami ${ }^{22}$. Potym, nazajutrz, przyszedł car $z$ wojskiem sprawionym $^{23}$ pod Czernieow. A obaczywszy złą sprawę Kozaków, posłali do ich obozu, frasując się na nie barzo a rozkazując, aby to powracali, co pobrali, mianowicie fanty, alias tedy car z rycerstwem inszem bitwę im da. Przysłali tedy Kozacy, prosząc cara i rycerstwa, obmawiając się, dawając sprawę o sobie, że barzo wiele mają zabitych i posieczonych ${ }^{24}$ "Ażeśmy to miasto dlatego ubiegli, abyśmy się mogli carowi przysłużyć, obawiając się, aby się Moskwa zmocniwszy nie byli nam silni”. Jednak przecie zatrzymał się car do kilku dni, przykazawszy, aby powracali fanty, które Kozacy, choć nie wszystkie, oddali. A car z panem wojewodą tuż pod Czernieowem położył się obozem. Tam rycerstwo prosiło cara o pieniądze, uskarżając się na niedostatek swój jako w odzieniu, tak i w żywności. I wziąwszy car z zamku czarnieowskiego dziesięć tysięcy, podzielił między rycerstwo i tam tydzień pod Czernieowem odpoczywaliśmy.

Stamtąd ruszyliśmy się pod Nowogródek, do którego było od Czernieowa mil 36, wszystko lasami. Kozacy przyszed[ł] szy pod Nowogrodek ${ }^{25}$, który leży nad tąż rzeką Desną, chcieli puścić do szturmu, lecz się obawiali tekiegoż kłopotu od cara, jaki mieli o Czernieow ${ }^{26}$ z strony plondrowania. A w tym Bosman $^{27}$, sprawca zamku tego, popalił miasto i przedmieścia, a sam się zamknął na zamku. Przyszedł potym carowicz z wojskiem swym sprawionym i posłał na traktaty pod zamek kilkunastu, a mianowicie pana Matiasza Domarackiego ${ }^{28}$, pana Stanisława Borszę, pana starostę ostrskiego, Białoskórskiego 29 i inszych niemało, także Moskwy z Morawska. Jednak Moskwa nie chciała przystąpić do traktatów,

${ }^{19}$ RIB: nim by.

20 RIB: plądrowano.

${ }^{21}$ Przeradowscy herbu Półkozic pochodzili z ziemi różańskiej. Wawrzynicc z Przcradowa był posłem na scjm z roku 1589, Jan zaś dworzaninem królewskim (Niesiccki, t. 7, s. 538), brak pewności, o którcgo z Przeradowskich tu chodzi.

${ }_{22}^{22}$ RIB: przed dumami.

23 RIB: sprawnym.

${ }_{25}^{24}$ RIB: rannych.

${ }^{25}$ Nowogród Siewicrski - miasto i gród na północny wschód od Czcrnichowa, nad tąż rzcką Desną.

${ }_{27}^{26}$ RIB: pod Czcrniejowem.

27 Bosman - Piotr Basmanow, cncrgiczny dowódca twicrdzy Nowogrodu Sicwicrskicgo, pragnący dochować wicrności Borysowi Godunowi.

${ }^{28}$ Matiasz (Maciej) Domaradzki herbu Gryf, z zicmi sanockiej, rotmistrz w służbic Dymitra, poległ razem z Borszą w czasie rewolty w maju 1606 roku.

${ }^{29}$ Hermolaus Białoskórski herbu Abdank, z zicmi halickicj, towarzysz w rocic konncj w służbic Dymitra, później w wojsku królcwskim. 
i owszem, strzelali na naszych potężnie, wołając na naszych: „A blady ${ }^{30}$ synowie, przyjechaliście na nasze dęgi ${ }^{31} z$ worem ${ }^{32, "}$.

Położywszy się wojsko obozem nad rzeką Desną, od zamku ćwierć mile abo pół mile równe, tam zaraz kazano pod zamkiem szańce kopać, pleść kosze. Tam wprowadziwszy działek niewielkich polnych 8, a śmigłownic na kołkach i na szrobach 6, strzelali do zamku próbując, ażeby się chcieli poddać, i natenczas, kto był ochoczy ${ }^{33}$, pozsiadali z koni naszy usarze i chodzili do sztur$\mathrm{mu}$, a insze roty stały w polu, i po dwakroć naszych Moskwa odstrzelała od zamku. Trzecia raz w nocy, porobiwszy szturmy drzewiane albo baszty na saniach, prowadząc je przed sobą, takośmy szli pod zamek cicho. Przy tym szło do 300 ludzi z namiotami, to jest z słomy i z chrostami, chcąc potym te chrusty zapalić około zamku, i podszed[ł]szy pod zamek, miotali chrusty pod zamkiem w rów. Moskwa się postrzegła i strzelali z dział, i tak niemało naszych poszkodzili. A trwał ten szturm do świtania, począwszy się z wieczora ${ }^{34}$. Widząc naszy, że i podobieństwa do dobycia zamku nie było, nie mając potężnej armaty do tego, którą by mogli dziurę wybić, odstąpili z niemałą szkodą swych. Zaczym carowic będąc barzo żałosnym, aż prawie omdlewał od frasunku, narzekając na nieszczęście swoje i na Polaki, mówiąc te słowa: „Iżem ja coś więtszego rozumiał o Polakach, ale widzę, też ludzie, jako i drudzy ${ }^{35}$ ". Rycerstwo w tym krzyknęło, które natenczas było przy carowicu: „Nie ujmuj nam dobrej sławy, ponieważ to widzą wszystkie narody, iż nam nie nowina mocnych zamków szturmem dobywać, choć tego powinność nasza nie niesie, abyśmy do szturmu mieli chodzić. Jednak poprawiając sławy przodków swych, nie zbranialiśmy się tego do tych czasów i zbraniać się nie chcemy, tylko każ dziurę wybić. A jeżeli ${ }^{36}$ nam przyjdzie potkać się polem z twym nieprzyjacielem, tam WM poznasz, Mości caru ${ }^{37}$, dzielność i męstwo polskie, o którym teraz mało rozumiesz". I niedługo potym napatrzył się dzielności Polaków naszych $i$ inaczej by potym rozumiał o nich. Przyszło potym naszym do tego, że wątpili o jego sprawiedliwości. Aż nazajutrz, z łaski Pana Boga Najwyższego, przyszła nowina pocieszna, iż posłowie idą $z$ miasta Putywla ${ }^{38}$, mil 15 od Nowogrodka, z poddaństwem od putywlanów. Co takiem sposobem się stało, za dziwną sprawą Bożą, iż halabartnicy carscy, Moskwa, którzy jeszcze z Sambora przyszli z carem, jachali dla żywności pod Putywl, których Moskwa z Putywla pojmawszy, pytała, co są za ludzie. Oni jem dali tę sprawę: „Żeśmy są bracia waszy, którzy idziem do ojczyzny z Dymitrem Iwanowiczem, z panem naszym przyrodzonym". I nie dufając im w tej mierze, chcieli ich wziąć na próbę, którzy im powiedzieli, że „gardła nasze w rękach waszy są, wolno wam poczynać z nami, jako chcecie. Jednak my nie możem inaczej zeznawać, \{jedno\} jako wiemy

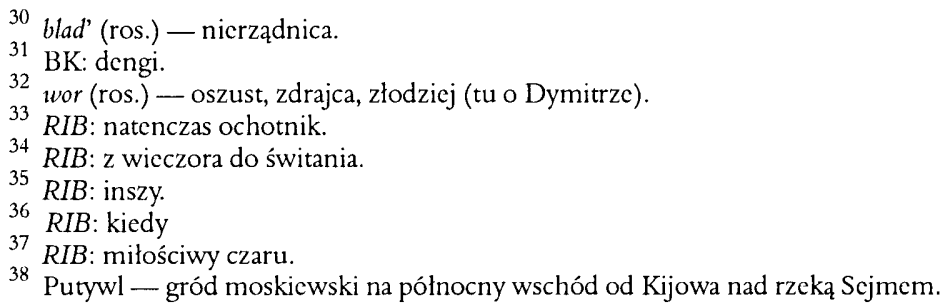


i czegośmy doznali, iż jest prawdziwy dziedzic, i wam radzimy, abyście się mu pokłonili”. Oni to dobrze u siebie uważywszy i naradziwszy się społem, powiązali wojewody i przywiedli je do obo-

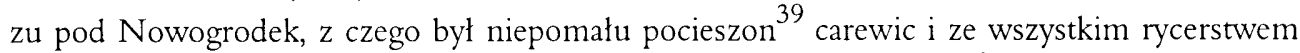
swym, gdyż potym zaraz trzeciego albo czwartego dnia poddało się wiele ${ }^{40}$ zamków, a mianowicie Rylsk i Komarska Włość $c^{41}$.

Przywieziono potym z Putywla dział burzących 5, a mniejszych także 5, i wprowadziwszy je w szańce, upatrzywszy miejsca lepsze szańcom, strzelano z nich do Nowogrodka barzo potężnie i ubito pierwszego dnia w zamku ludzi do 60 , bo kule przechodziły na wylot. A strzelano $z$ nich niemal cały tydzień we dnie i w nocy.

Przyszła do nas potym wieść, iż idzie na odsiecz wojsko Borysowe ${ }^{42}$, barzo wielkie, którego powiadali być dwakroć sto tysięcy ${ }^{43}$. Naszy się tego, z łaski Bożej, nie strachając, zebrawszy się na czatą, kto ochoczy, z różnych rot, szli pod wojsko Borysowe $z$ dobremi i pewnymi kalauzami ${ }^{44}$ moskiewskiemi, obrawszy sobie z pośrodku siebie starsze i wodze. Z wojska także Borysowego wyprawiła Moskwa Tatarów na czatą kilka tysięcy. Naszych nie było więcej od 800, z którymi-śmy się zeszli w nocy insperate ${ }^{45}$ i daliśmy im bitwę, którzy, z laski Bożej, zaraz tył podali, i nagnaliśmy ich do błota, gdzie ich wiela potonęło, i więźniów dostaliśmy niemało ${ }^{46}$, to jest do kilkudziesiąt, którzy nam dali dobrą sprawę o wojsku na mękach, że barzo wielkie.

W tydzień potym ono wojsko Borysowe przyszło na nas w nocy pod Nowogrodek, prawie do samego obozu, aż straż nasza ustąpiła do obozu, dawając znać o wielkim ludzie. Potym JM pan wojewoda, będąc hetmanem, posłał straż świeżą ${ }^{47} \mathrm{z}$ obozu, aby straż trzymali ${ }^{48}$, aż Pan Bóg da dzień. Nazajutrz, wziąwszy Pana Boga na pomoc, zatrąbiwszy \{cicho\} przez munsztuk, wyszło wojsko $z$ obozu w pole przeciwko nim. Moskwa też potężnie stanęła, przypatrując się sobie a harce zwodząc. A Bosman nie omieszkiwał wycieczek częstych czynić z zamku, strzelając z dział naszych $^{49}$. Dla tego naszy Kozaków na to kilkaset odłączywszy, kazali mieć na nie [pilne] oko, którzy ${ }^{50}$ ich wsiekali kilkakroć w samy zamek. A w tym wieczór zaszed1 ${ }^{51}$, bo dzień ten zszedł na traktatach, które z Moskwą carowic czynił, i dlatego bitwy nie dal. Aż nazajutrz, kiedy inaczej być nie mogło, przyszło wojsko moskiewskie barzo wielkie, które $\{a z ̇\}$ do samego obozu przyszło; będąc naszy pogotowiu, wyszli z obozu w sprawie. Tam uszykowawszy wojsko, jako najlepiej rozumieli, kazano się potkać rocie pana Nieborskiego ${ }^{52}$ ze 200 koni, i uderzył się dobrze o nich, jednak przecie sparła go

${ }^{39}$ RIB: ucieszony.

RIB: kilka.

41 Rylsk — gród moskicwski położony na północny wschód od Putywla, nad tąż rzcką Scjm; Komarska Włość — tamżc.

42 Borysa Godunowa - ówczesnego cara moskicwskicgo.

43 RIB: było na dwicście tysiçcy.

44 Kalauzowic (kałałzowic) - przcwodnicy.

${ }_{45}$ RIB: inspate; insperate (lac.) - nicoczekiwanic.

46 RIB: siła.

47 RIB: z wieżą.

48 RIB: aby strzegli.

49 RIB: strzclając na nas.

${ }_{51}^{50}$ RIB: ci; BK: którzy.

51 BK: a w tym dzień zszedł.

52 Piotr Nieborski, rotmistrz w wojsku Dymitra, dowodził 200-konną rotą usarską; wsławił sic̨ odwagą, wspomina o nim Niesiecki, t. 6, s. 534. 
Moskwa. On, odwiod[1]szy rotę, przyszedł znowu do sprawy, skoczył do nich ze dwiema rotami, z Kruszyną i z Bilińskiem ${ }^{53}$. Dworzycki nie mieszkając z rotą swą petyhorską potkał się mężnie, że prawie zamieszali Moskwę. Skoczyły potym dwie rocie usarskie, pana starosty sanockiego i pana Fredrowa, i pana Szczuczyna 54 rota trzecia, posiłkując ich dobrze. A gdy czwarta rota się potkała, carska, pod którą było 200 koni, znaczną posługę uczynili, bo zaraz ono wielkie moskiewskie wojsko poczęło ustępować. Były jednak roty posiłkowe, które się nie potykały, iż tego nie było potrzeba. A strzelcy Borysowi, którzy byli w dolinie zasadzeni, których było kilka tysięcy, nie zaraz byli od nas postrzeżeni, przywiedli na nie piechotą naszą polską, która ich wszystkich za pomocą Bożą pogromiła. I tak, za pomocą Bożą, otrzymaliśmy plac i zwycięstwo, a wojsko to Borysowe odemknęło się od nas ze dwie mili, obrąbawszy się i okopawszy w lasach. Natenczas naszy odjęli byli choragiew moskiewską złotą, barzo kosztowną, która była wszystkiego wojska.

Nazajutrz, podług zwyczaju krześcijańskiego, chowano moskiewskie ciała zabitych, uczyniwszy trzy mogity, barzo wielkie, na pobojowisku. Tam miotano Moskwę ${ }^{55}$, których mogło być do 6000 , czego car z wielkiem żalem i placzem używał, jeżdżąc między trupy, widząc tak wiela ludzi swych pobitych. Polaków zaś swych pobitych, a zwłaszcza znaczniejszych, nie było więcej 20, których chowano z uczciwością wielką w obozie przy cerkwi, która była w pośrodku obozu. A inszych ludzi pospolitych naszych zginęło ze 100, których niedaleko moskiewskich ludzi pochowano w małej mogile. Tamże było naleziono między trupy Mścisławskiego ${ }^{56}$ haniebnie $\{$ bardzo\} usieczonego.

Po tej pierwszej potrzebie rycerstwo nasze cknęli sobie, iż niedostatek wielki cierpieli, tak oni sami, jako i czeladź ich. A niektórych też podobno strach przywodził do tego, obawiając się niebezpieczeństwa więtszego, upominając się pieniędzy carowi, deklarując mu się, że „jeśliż pieniędzy nie dasz, my zaraz idziem do Polski nazad”. Carowic prosił barzo, aby byli cierpliwi, ażeby zaraz nie mieszkając konali tego nieprzyjaciela, który jest barzo przestraszony i zatrwożonny $^{57}$. Rycerstwo na to słowa nie dali rzec, owszem, „do Polski iść, jeśli pieniędzy nie dasz”.

53 Kruszyna, Biliński (Bicliński) — rotmistrzowic w wojsku Dymitra.

54 RIB: Szczuki; BK: Szczuczkiego. Wacław Szczuka, rotmistrz w służbic Dymitra I Sawozwańca, a późnicj Dymitra II, następnic na służbic królewskicj i w konfederacji wojsk „stołecznego” Józefa Cicklińskicgo.

55 BK: ciała moskicwskie.

56 Inni pamiçtnikarzc podają więccj szczegółów na temat tcj pierwszej wiclkicj bitwy z wojskami Borysa Godunowa: „tcgo dnia poszli naszy do Nowogródck [tj. Nowogródek Siewierski], na którym zastali ludzi zawartych dworu Borysowego, do tysiąca strzelców. Przyszło im tam leżeć niedziel ośm, dostawając tego zamku, co gdy się działo, przyszło na odsiccz Moskwy (działo się to roku 1604 ultima Decembris) pewnej liczby 40 000, które naszy za Bożą pomocą pogromili”. (Diariusz Waclawa Dyamentowskiego, op. cit., s. 13-14). W Pamiętniku... Samucla Maskicwicza dalsze szczcgóły: „Moskwa pod Nowogrodem stawiła im pole, dufając wiclkości swoich, których było 80000 . Kniaź Mścisławski wodzem był u nich. Nasi tę potrzebę wygrali za pomocą Bożą i samego Mścisławskiego byli pojmali, ale go odgromiono" (Pamiętniki Samuela i Boguslawa Kazimierza Maskiewiczów, op. cit., s. 96). Historyk rosyjski S. M. Sołowiew dorzuca jeszcze kilka innych informacji. Dowództwo nad wojskiem przeciw Samozwańcowi zostało powierzone jednemu z pierwszych bojarów, kniaziowi Fiodorowi Iwanowiczowi Mścisławskiemu, którcmu car Borys obiccał wydać za nicgo swą córkę i nadać mu Kazań wraz z Zicmią Sicwierską. Kniaź Mścisławski otrzymał pod swą komendę 40-50 tys. wojska przeciw 15 tys. wojsk Samozwańca. W stoczoncj 21 grudnia bitwic wojska Borysa poniosły druzgocącą klęskę, tracąc 4000 zabitych. Sam Mścisławski został kilkakrotnic ranny w głowę. Dymitr na widok tylu zabitych Rosjan zalał siç łzami (Istorija Rossii s drewniejszych wremien, kn. 4, t. 7-8, Moskwa 1960, s. 418).

57 RIB: bardzo przestraszonego i strwożonego. 
Carowic, widząc, iże źle, radził się, co z tym czynić, nie mając podobno sto pieniędzy, aby miał wszystkim dać. Towarzystwo $\{z$ roty $\}$ pana Fredrowej potajemnie poczęli mówić: „Abyś Wasza Carska Mość raczył dać jedno nam pieniądze, żeby drugie roty o tym nie wiedziały, gdyż insze roty na nas patrzą; jeśliż się my zatrzymamy, wszyscy zostaną". I tak carowic nieborak będąc uwiedziony, dał im pieniądze w nocy, czego się insze roty dowiedziawszy, zbuntowały się, obrażając się tym do carowica, że tylko jednej rocie dał pieniądze, a drugiem nic. Pan wojewoda też będąc chory, ukazując też potrzeby swoje, na sejm ruszył się z obozu od carowica, a z nim rycerstwa więtsza część. Był natenczas carowic barzo żałosny i utrapiony, gdyż go tam rozmaite rzeczy potykały od rycerstwa, bo i choragiew mu jego byli wzięli, nawet ferezyją z niego zdarli sobolą, aż ją Moskwa wykupiła we $300 \mathrm{fl}$ [orenów] ${ }^{58}$. Do tego mowy sprośne mówiąc, że „ty dalibóg będziesz na palu”, rzekł jeden, któremu carowic dał za to w gębę. \{Potym\} carowic nieborak, jeżdżąc od roty do roty, prosił dla Pana Boga, padając krzyżem, aby nie odjeżdżali. Oni żadnem sposobem nie chcieli się zostać, chyba z różnych rot po kilku, po kilkanaście towarzystwa, kto ochoczy. Owo nie zostało przy carewicu ludzi polskich wszystkich a wszystkich człeka z półtora tysiąca. Idąc to wojsko z panem wojewodą przez pola dzikie do Polski, użyli wielkich niedostatków, głodu i zimna, i konie ich, i narzekali jedni na drugie, którzy byli tego odjazdu ich przyczyną, gdyż więtszych niewczasów używali idąc, niż ci, co zostali przy carewicu.

Zatym po odjeździe pana wojewodzinym i tego rycerstwa, które z nim poszło, przyszli Kozacy zaporoscy we 12 tysięcy, którem był dawno carowicz posłał choragiew, i mieli z sobą kielkanaście działek armaty grzecznej, którym carowic barzo rad, rozumiejąc siła o męstwie ich, ponieważ wojsko było barzo ogromne. Wziąwszy się tedy z tymi Kozaki i z trochą Polaków, poszedł z niemi do Komarskiej Włości, dalej w ziemię moskiewską. Tam sobie rycerstwo po wielkich niewczasiech przez dwie niedzieli dobrze wytchnąwszy, nie chcąc próżnować, o wojsku wiedząc, na czaty chodzili, która idzie na 8 mil. A przed tym, niż się było wojsko ruszyło spod Nowogrodka do Komarskiej Włości, przysłali rylszczanie do carowica posły swoje, prosząc go, aby im dał do Rylska Polaka, człowieka takiego, któremu by mógł ufać, jakoz ${ }^{59}$ i samemu carowi JMci zdało się za rzecz słuszną i potrzebną. Wyprawił tedy nie mieszkając i prosząc pana Stanisława Borszę, dworzanina i rotmistrza swego natenczas, aby tam jechał, a opatrzywszy i obwarowawszy zamek żywnością i inszemi potrzebami, wrócił się do cara na jego rozkazanie. Choragiew wziąwszy zebrał towarzystwa 200.

A wojsko Borysowe dowiedziawszy się o odjechaniu pana wojewodzinym i inszego rycerstwa tak wiele, wzięło stąd wielkie serce przeciwko nam i przymknęło się do nas jakoby w sześciu mil. Carowic radził się, co czynić, mianowicie Kozaków najwięcej, gdyż był w nich wszytkę nadzieję swą położył. Hetman z pułkownikami radził, aby iść do nich, nie czekając ich. Polakom się zaś nie zdało niektórym, ale żeby ich czekać na miejscu, upatrzywszy sobie miejsce dobre do potkania, a więcej ich kontraktami zażywać i zrozumiewać, nie skwapiając się do bitwy. Jakoż tego \{wszyscy\} potym doznali, że to była dobra rada. Co i sama Moskwa potym powiedziała, mówiąc „żeśmy

${ }^{58}$ Czyli 300 ówczesnych złotych polskich, obiegowej monety, w przeciwieństwie do złotych czerwonych o wyższym nominalc.

59 RIB: co się. 
się byli do pokoju nakłonili, widząc wasze wojsko ogromne”. Kozacy przecie przy swym zdaniu upornie stojąc, radzili, aby koniecznie iść do nich. W czym carowic rady ich posłuchawszy, ruszył się ze wszystkiem wojskiem spod Siewska ${ }^{60}$, obrawszy sobie Polaka hetmanem, pana Adama Dworzyckiego, który był przedtym pułkownikiem. Tam przyszli prawie ku obozowi moskiewskiemu $^{61}$ niedaleko, a wojska moskiewskie w sprawie stały czekając nas, którego było więcej 30000 niż pod Nowogrodkiem, które wojsko sprawował brat stryjeczny Hodunow, Siemion Odon, Szujskich ${ }^{62}$ dwa bracia ${ }^{63}$.

Sprawiwszy się Polacy porządnie, postąpili dalej ku lewemu skrzydłu wojska moskiewskiego. A Kozacy prawe skrzydło wzięli. Sprawiwszy Polacy siedm rot kopijników, mieszając usarza z petyhorcy w jeden ufiec, zostawiwszy na posiłek usarzów dwieście, których pan Białoskórski wiódł. Tam, wziąwszy Pana Boga na pomoc, potkali się trzy roty. Naprzód pana Dworzyckiego, hetmana, potym pana Stanisława Borsze, pana Wierzbickiego ${ }^{64}$, pana Kruszynina, pana Bieleńskiego $^{65}$, pana Tyszkiewiczowa ${ }^{66}$ i pana Mikulińskiego ${ }^{67}$. I tak się mężnie potkali, aż wparli ${ }^{68}$ Moskwę w obóz, gdzie naszy przyszli na strzelbę barzo gęstą, którą gdy Moskwa na naszy wypuściła, jako grad, jednak z łaski Bożej nie barzo szkodziła, bo przenosili. A dym od tej strzelby poszedł na Kozaki, którzy prawe skrzydło trzymali. Ani się potkawszy, wszyscy nazad przed dymem uciekli. Polacy rozumiejąc, iż się Kozacy potykają ${ }^{69}$ z Moskwą jako i oni, spierali Moskwę tym więcej, nie wiedząc, co się z Kozaki w dymie działo. A iż kielka z Polaków przypadło, dając znać, iz już Kozacy uciekli. I tak uchodziliśmy obronną ręką przychodząc do sprawy, spierając Moskwę. A piechota jednak kozacka, która była przy armacie, zastanowili się do obozu przeciwko Moskwie, ale nie mogąc strzymać tak wielkiemu wojsku, ustępowaliśmy nazad, spodziewając się, ażeby Kozacy odwrót uczynili. I onej piechoty żadnym sposobem ratować-eśmy nie mogli, którą tam Moskwa pogromiła i armatę pobrała. Puściliśmy się zatym po Kozakach, kto miał rączego, upominając i prosząc, aby tej niesławy na się nie nawłoczyli ${ }^{70}$. Oni na to nic nie dbając, sromotnie uciekali tam i sam. Carowic ściął ich kilku, nawracając ich $z$ inszemi Polaki. I takieśmy szli za Kozaki aż do samego Rylska mil 18, nie pokarmując, aż do Rylska przyszed[ł]szy, spoczywaliśmy dwa dni.

Ruszyliśmy się do Putywla, od Rylska 12 mil od granicy polskiej, a wojsko Borysowe po nas szło, spodziewając się nas w Rylsku zastać, które przyszło pod Rylsk nazajutrz po nas i tamże się obozem położyli. Moskwa kosze zaraz kazali pleść i kopać szańce. Podszańcowawszy się pod miasto i armatę wprowadziwszy w szańce, strzelali potężnie do miasta Rylska, a rylszaczanie się też

\footnotetext{
${ }^{60}$ Sicwsk - gród moskicwski położony na północ od Rylska.

61 RIB: nicprzyjacielskicmu.

62 Siemion Godunow - brat stryjeczny cara Borysa i dwaj książçta Szujscy.

${ }_{63}$ RIB: pod sprawą brata stryjecznego Hodunowego Siemiena Hoduna i Szujskich dwu bracicj.

64 Wicrzbicki, rotmistrz w służbic Dymitra. Nicsiccki wymicnia piçć rodzin o tym nazwisku i różnych herbach, nie wiadomo, do którego rodu nalcżał interesujący nas tu Wierzbicki.

${ }^{65}$ RIB: Biclińskicgo.

66 Samuel Tyszkicwicz, pułkownik, późnicj w slużbic Dymitra II Samozwańca w 1607 roku.

${ }_{67}^{67}$ Mikuliński - możc Iwan (Jan), pisarz ziemski bracławski, rotmistrz, później w służbic Dymitra II Samozwańca.

${ }^{68}$ RIB: wsparli.

69 RIB: potykają

${ }^{70}$ RIB: wewłóczyli.
} 
potężnie bronili, będąc upewnieni od carewica, że im miał przysłać wojsko na odsiecz. Jakoż jednak posłał 2000 Moskwy, a Polaków 500, którzy nocą weszli w miasto tak sztucznie, iż ich Moskwa nie postrzegła, aż weszli. Tóz dopiero obaczyli, a carewic upewniał ich znowu, że miał przyść jako najprędzej z niemały[m] wojskiem Polaków na odsiecz. O czym się dowiedziawszy wojsko Hodunowe, niepomału sobą trwożyli, a my jeszcze barziej, obawiając się, aby do nas nie przyszli, ponieważ nas barzo niewiele było, gdyż po $\{$ tej\} przegranej bitwie, którąśmy mieli pod Siewskiem, siła ich poszło do Polski, nie żegnając. Owa zgoła prawie wszyscy poszli, aż carowic usilnie począł prosić pana Hermolausa Białoskórskiego i pan Stanisława Borszę, aby za niemi jechali, prosząc dla Pana Boga, aby się wrócili, na których perswazyją, za pomocą Bożą, wróciło się ich niemało i coś niewiela ich poszło do Polski.

Przyszed[1] szy do Putywla, nazad prawie jako znowu zgromadziliśmy ${ }^{71}$ towarzystwo pod chorągwie, gdyż się byli pomieszali to tam, to sam. Wprawili znowu w swą klubę roty panowie rotmistrze, drzewek jako najwięcej narobiwszy, na których było rycerstwo zeszło, bo jedni w potrzebie pokruszyli, drugie pomiatywali uchodząc. Puścilichmy potym ten słuch, iż nam idzie wojsko Polaków niemało na posiłek, a mianowicie pan Żółkiewski, hetman polny, chociaż nie było podobieństwa tego.

Moskwa Borysowa dostawszy języka, Moskwicina z Putywla, pytali go, co myśli carowic $z$ wojskiem swym. I dał im tę sprawę, jaki rumor ${ }^{72}$ był w mieście Putywlu, iż idzie wielkie wojsko na posiłek Polakom. Oni temu uwierzywszy, zatrwożywszy się barzo, ruszyli się z obozem od Rylska i tak prawie uchodząc, odemknęli się od nas \{prawie\} 40 mil od Rylska, pod Kromy ${ }^{73}$, z czego byśmy niepomału byli pocieszeni. Potym carowic JM wyprawił z Putywla i z Rylska ludzi 4000 Kozaków duńskich i z Moskwą na odsiecz kromianom, którzy także weszli cicho nocą w miasto, których nie obaczyli, aż ku końcowi, i tak się z nimi Moskwa biła, aż się naszych prawie ostatek wbił w miasto. Gdy tedy naszy przyszli na pomoc do Kromów, dopiero z wojska Borysowego haniebnie strzelano $z$ dział i moździerzów wielkich, aż zamek kromski spalili z dział. Ale kromianie, nie ustawając, bronili się barzo potężnie, wycieczki czyniąc do nich częste. I tak Borysowe wojsko leżało 7 lub 8 niedziel pod tymiż Kromami, dobywając miasta wielką moca. Przychodziły zatym do Putywla częste wieści do nas, iż Kromów dobyto przez moc, skąd było wielkie zatrwożenie między nami, gdyż było wielkie narzekanie w mieście, żonki opłakujące mężów i synów swych. Dla czegośmy byli w wielkim niebezpieczeństwie obawiając się, aby nas putywlscy nie zdradzili, chcąc się przysłużyć Borysowi. A zatym przyszło $500^{74}$ strzelców z Borysgoroda i Carygroda ${ }^{75}$, przedając się carowi, którzy byli w czerwonej barwie, bo byli służebni Borysowi. Zatym prędko przyszła wieść nieodmienna ${ }^{76}$, a wielce nam wszystkim pocieszna, o śmierci Borysowej ${ }^{77}$. A w tym żona Borysowa posłała z Moskwy miasta w skok do wojska, które

${ }^{71}$ RIB: zwodziliśmy.

72 RIB: zamiar; BK: rumor.

73 Kromy — gród moskiewski położony na pólnoc od Kurska.

${ }^{74}$ BK: 100

75 Borysgorod i Carygorod — grody założone przez Borysa Godunowa.

${ }_{77}^{76}$ BK: nicomylna.

${ }^{77}$ Śmierć Borysa Godunowa nastapiła 13 kwictnia 1605 roku, wg jednej wersji na skutck otrucia, znawca zagadnic- 
było pod Kromami, aby przysięgali synowi jej, Fedorowi. I siła ich było, którzy przysięgali. Jednak w tej mierze stał się rozruch niemały. A my o wszystkim mając dostateczną wiadomość, nie mogąc się doczekać żadnego żywego człeka z Polski nam na pomoc, ruszyliśmy się z carowicem przeciwko tamtemu wojsku, nie mając więcej wojska, telko 2000 kopijników, a Moskwy mogło być 10 tysięcy.

Ruszywszy z Putywla, wyprawiliśmy wprzód przed sobą trzy roty Polaków, to jest pana Zaporskiego $^{78}$ starszem uczyniwszy i kilka tysięcy Moskwy. Gdy już było niedaleko Kromów, zażył pan Zaporski tej sztuki: napisał list po moskiewsku do kromianów, takiem sposobem: „Oznajmuję wam, iż wam idziemy na odsiecz z potężnym wojskiem Polaków”.

Z którym listem wyprawił Moskwicina, wziąwszy ze wsi Bilromy ${ }^{79}$ Borysowej, ukazawszy mu kilka rot i dawszy mu rubl, aby ten list doniósł do mieszczan kromeńskich, którego posłańca pojmano z wojska Borysowego i przywiedziono do obozu, wziąwszy list, czytali, które należały kromianom, który przeczytawszy, wielce się zatrwożyli. A w tym straż moskiewska, Tatarowie, będąc pogromieni od pana Zaporskiego, przybiegła do obozu, powiadając o wielkim barzo ludzie, gdyż naszy z lasa wychodzili, których się Tatarom siła zdało i niepomału Moskwę zatrwożyli, gdyż się ich powieść zgadzała z listem, który pan Zaporski na to posłał umyślnie, aby go pojmano. A w tym z onego strachu Moskwa wyprawili posły swe przeciwko panu Zaporskiemu, oznajmując $\mathrm{mu}$, że „my czołem choczemy uderzyć Dymitrowi Iwanowiczu i chrest zaraz wojsko wszystko całuje”. O czym zaraz dał znać pan Zaporski carowicowi. Moskwa zaraz z wojska przybieg[ł]szy, dając znać, iż „wielkie wojsko tobie czołem bijut, a twoje zmienniki powiązaliśmy”. Z czego wszystkiego car był barzo pocieszon i my wszyscy, którzyśmy natenczas z nim byli w wielkiem niebezpieczeństwie. Przy tym przyjechał książę Haliczyn ${ }^{80}$, który był między inszymi hetmanem $z$ kilkaset człeka, oznajmując mu o tym, iż „wszystko ${ }^{81}$ wojsko tobie posłuszne jest (pana Borszyna rota natenczas była na straży i porucznik przysłał do pana Borszę tę nowinę) i wsia ziemla".

My już też w drodze będąc z carowicem, ruszyliśmy się dalej ku stolicy, a do tamtego wojska posłał zaraz carowic, aby się rozjechali ${ }^{82}$, bo było strudzone, a co przedniejszym kazał się czekać pod Orłem ${ }^{83}$ zamkiem. Przyszliśmy potym z carowicem pod Orzeł. Tam wyjechało wojska moskiewskiego przeciwko nam, \{jako\} powiadano, być w liczbie $80^{84}$ tysięcy, i takeśmy go prowadzili, za pomocą Bożą, ku stolicy szczęśliwie. Jednak wojsku tamtemu nie ufając przecie, carowic kazał je w pólmilu stawiać od siebie, czasem w mili, a my, Polacy, tuż około niego na stanowiskach i w ciągnieniu aż do samej stolice, straż około niego nocną miewając ${ }^{85}$ po 100 człeka.

nia Rusłan Skrynnikow twicrdzi, że na skutck apopleksji (R. Skrynnikow, Borys Godunou', op. cit., s. 187-188).

${ }_{79}^{78}$ Zaporski - Jan lub Tomasz, marszałek dworu Stanisława Mniszcha, starosty sanockicgo.

79 RIB: Bilzony; BK: Borysowy.

${ }^{80}$ Haliczyn - kniaź Iwan Golicyn, obok Wasyla jeden z uczestników spisku przeciw Borysowi Godunowi.

81 BK: wiclkic.

82 BK: rozchodzili.

83 Orzeł - miasto na północny wschód od Krom.

${ }_{85}^{84}$ BK: 50.

85 RIB: nocą trzymając. 
Potym 15 mil będąc od Moskwy pod Sierpuchowem ${ }^{86}$ zamkiem, rozbito zamek z namiotów, który wysłano z Moskwy przeciwko carowicowi, barzo wielki i kosztowny, o czterech bramach z basztami, które się zdały jako zamek murowany ${ }^{87}$. Pokoje barzo kosztowne i złotem dziwnie haftowane, mianowicie izba stołowa, gdzie nas car częstował i bojary, gdzie siedziało człeka z $500^{88}$, których częstował wielkiem dostatkiem, ponieważ byli zajechali kucharze z Moskwy ze wszystkiemi potrzebami, z inszymi urzędnikami, klucznikami także. Koni wyszło na powodzie 200 , których zawsze do 500 na staniu carskim ${ }^{89}$ i karet kilka z poszós[t]nemi ${ }^{90}$ woźnikami barzo pięknemi. Takeśmy szli ku Moskwie, a co dzień to potykali cara bojarowie, przynosząc upominki, sobole, srebro, złoto.

I weszliśmy za pomocą Pana Boga Najwyższego na stolicę, z łaski Pańskiej mając piękne pogody, gdzie ludzi barzo wiela wieszało się na dachach, narodowi polskiemu się przypatrując, któregośmy wprowadzili w samy zamek, w dziedziniec, stojąc w sprawie z chorągwiami przy pałacach, aż zsiadł z konia do pałaców. A stanowisko nam ukazano w jednym dworze poselskim wszystkiem choragwiam, gdzie nasz [ym?] było barzo ciasno. Jednak potym powoli powyprowadzali się byli drudzy.

Koronacyjej nie chciał odprawować, ażby matka jego przyjechała, która była w drodze. Czekał jej 4 niedziele. A w tym Szujscy, ludzie znaczni, chcieli zdradą nad niem i nad nami uczynić, zapaliwszy w nocy. Jednak żeśmy się postrzegli i carowic kazał ich pojmać i na plac wywieść. Za przyczynąjednak niektórych senatorów ${ }^{91}$, darowani gardłem, odesłani będąc na zamek daleko gdzieś od Moskwy, którzy są już przywróceni do łaski.

Koronacyja w kielka dni po przyjeździe matki jego \{była odprawiona $^{92}$, przeciwko której szedł pół mile piechotą, zsiad[ł]szy z wozu i z inszemi Polaki i gdy jechała przez miasto Moskwę, szedł [Dymitr] przy karecie. Rychło potym, po koronacyjej, stał się wielki rozruch między Moskwą a Polaki, a to z tej miary, iż Moskwa za małą przyczyną szlachcica polskiego Lipskiego ${ }^{93}$, towarzysza naszego, kazała katom knotować, wodząc po ulicach podług zwyczaju swego. Naszy to obaczywszy, do nich, i tam siła pobitych legło na placu $\{i\}$ rannych barzo wiele. $Z$ czego był car barzo obrażony, posłał do Polaków, aby mu winnych wydano, alias tedy kazano armatą zatoczyć i znieść do gruntu z dworem, i nie każąc żywić i najmniejszego dziecięcia.

Polacy na to poselstwo jego tak wskazali: „Takaż to nagroda ma być za nasze krwawe posługi, któreśmy dla cara podjęli? My się tego nie strachamy i niechaj będziemy męczennikami. Będzie jednak JKM, pan nasz i bracia naszy o tym wiedzieć. A my tymczasem chcemy zginąć jako ludzie rycerscy i póki nie pomrzemy, nabroim siła złego". Była tedy taka rezolucyja między rycerstwem, iż chcieli wypaść do Moskwy, których było do kilkadziesiąt tysięcy, wołając księdza dla spowiedzi.

${ }_{87}^{86}$ Sierpuchow - miasto położone na poludnie od Moskwy.

${ }_{88}$ RIB: warowny.

88 BK: 3100.

89 RIB: stajni czarskicj.

90 RIB: porządnymi.

91 BK: przyjaciót.

${ }_{93}$ Odbyła się 21 lipca 1605 roku w Soborze Uśpieńskim, tradycyjnym micjscu koronacji carów moskicwskich.

93 Być może Adam Lipski. 
Dali tę sprawę carowi, iż tak są rezoluci Polacy, który się temu bardzo dziwował ich wielkiemu sercu. Posłał po wtóre do nich perswadując, aby się nie zbraniali winnych wydać, obiecując to, że się im nic nie miało stać, telko żeby tę pokorę uczynili dla tego, aby się Moskwa uspokoiła. I tak wziąwszy rycerstwo od niego upewnienie, wydało trzech z tą kondycją, iżby nie byli karani, "gdyż są niewinni, bośmy wszyscy bili, jedno się to czyni, dogadzając łasce Waszej Cesarskiej Mości”. Wydani tedy byli z roty pana Stanisława Borsze towarzysz jeden, Paweł Dzierzbicki ${ }^{94}$, z roty pana Wierzbickiego - Szczygielski ${ }^{95}$, z roty pana Boguchwałowej ${ }^{96}$ - Szeliborski ${ }^{97}$, których nam obiecał car w cale oddać. Jednak w wielkim strachu byli, bo ich było wsadzono do niebezpiecznej wieże, gdzie były wewnątrz około muru ławki wąskie, a pod ławkami rozmaite haki, kosy, pale żelazne; gdyby się był który zdrzymał, zaraz by był dał haniebnie gardło, i gdyby tam byli dłużej, już się mieli spuścić, bo tam telko przez dzień i przez noc byli.

Rotmistrze ci byli natenczas, którzy cara wprowadzili na stolicę: pan Dworzycki, hetman; pan Stanisław Borsza, pan Iwanicki ${ }^{98}$, pan Białoskórski, pan Wierzbicki, pan Zaporski, pan Boguchwał.

Ta Historyja Moskiewska jest spisana przez pana Stanisława Borszę, rotmistrza i dworzanina wielkiego cara moskiewskiego Dymitra Iwanowicza die 4 Martii Anno Domini 1606.

\footnotetext{
${ }^{94}$ Pawel Dzierzbicki herbu Topór, zapewne tożsamy z uczestnikiem walk o Dorohobuż w 1610 roku w szeregach Dymitra II Samozwańca, o którym wspomina Diariusz drogi Króla JMci Zygmunta III, Wrocław 1999, s. 105, oraz konstytucja z 1616 roku (Volumina legum, t. 3, s. 139).

${ }_{95}$ Szczygiclski - towarzysz z roty Wicrzbickiego, postać bliżcj nicznana.

${ }^{96}$ Mikołaj Boguchwał, rotmistrz, późnicj w służbic Dymitra II Samozwańca (zob. diariusz Józcfa Budziły: Wojna moskiewska wzniecona i prowadzona zokazjifałszyurych Dymitrów od 1603 do 1612 r., opr. J. Byliński iJ. Długosz, Wrocław 1995, s. 82)

97 Szeliborski - towarzysz z roty Mikołaja Boguchwała, postać bliżej nieznana.

98 Iwanicki - może Wacław Iwanicki herbu Pełnia, uczestnik wojny moskicwskicj.
} 


\section{Aneks}

\section{Nowiny z Moskwy od Jana Wisłoucha do brata swego rodzonego, pisane do pana JakubaWisłoucha}

Rps Oss. 2284/II, s. 155-157; 24 VII 1605

Za łaską Pana Boga wszechmogącego szczęśliwieśmy przyjachali do Moskwy. Ruszyliśmy się z Putywla we czwartek przed Świątkami [26 V] starymi, JM tusząc sobie dobrze, jako żeśmy się z łaski Bożej w nadziei nie omylili, bo skorośmy przychodzili pod Kromy, gdzie wojska moskiewskiego było 70000 tysięcy [!], będąc od nich w piąci milach, wyprawiono nas pięć rot polskich, z którymi i sam pan hetman wojska cara JMci, pan Dworzycki szedł, Moskwy też mieliśmy tysiąc, Kozaków Zaporoskich pięćset. Tamże przyciągnęliśmy półtory mili do wojska Hodunowego. Zaraz pan hetman pisał list do kromian, którzy byli w oblężeniu, aby się mocno bronili, obiecując im przyść na pomoc w sześćdziesiąt tysięcy Polaków. Pan hetman umyślnie posłańca posłał do wojska Hodunowego, aby go pojmano, którego ułapiwszy, listy czytano. Usłyszawszy o tak wielkim wojsku naszym, Hodunowie jęli sobą trwożyć. Nazajutrz po posłańcu trafiliśmy na czatę moskiewską, gdzie było półtora tysiąca Hodunowych, z któremi mieliśmy zabawę, ale nie bawiąc się tył podała, a tak ich mało co uszło, do obozu goniąc, że obóz ich na okośmy widzieli. Ci gdy przypadli do obozu swego będąc potrwożeni, przybawili więcej trwogi w obozie swym, powiadając, że jest Liwy wojsko niemałe. Zaraz się w obozie poczęli mieszać: jedni ku Moskwie, zwłaszcza powinni Hodunowi, a drudzy carowi JMci przysięgać jęli, a zwłaszcza Bosman, pułkownik wojska Hodunowego. Zaraz z tym pułkiem wystąpiwszy przed cara JMci, przysięgę uczynił i drudzy także nań patrząc. Kromianie widząc ten rozruch między niemi, wypad[ł]szy z miasta, zaraz im armatę ubiegli, do kilkudziesięciu sztuk dział burzących odgromili. Tam też teraz między sobąjęli zdrajców łapać, mianowicie Iwana Hodunowa, który był starszym nad wojskiem tym. Interim prosili pana hetmana, aby z wojskiem do kromian naciągal, obiecując pewniejszą wiadomość o Hodunowie i o rozproszeniu wojska jego. Jakoż z łaski Iwana Haliczyna z kilkąset człowieka, którzy przed panem hetmanem przysięgę uczyniwszy, do cara JMci jachali i tak za łaską Bożą onę wielkość ludzi Hodunowych pokłon uczynili carowi. Stamtąd, nic się nie bawiąc, ruszyliśmy się w drogę ku Orłu, który wyszli, podając poddaństwo carowi JMci. Owa tak za łaską Bożą ubiegali się z każdego zamku, jeden przed drugim, kromia sama Moskwy miasto stołeczne, gdzie był syn Hodunów koronowany po śmierci ojca swego. Sam Hodun otrut, a pospólstwo wszystko przysięgali synowi Hodunowemu, przyjmując go za cara. Będąc pod Orłem, car JM wyprawił z listem do Moskwy do Szujskiego i do Mścisławskiego, żeby więcej nie byli przeciwko jemu, tak też i do pospólstwa. I gdy pisanie cara JMci do starszych Hodunowych przyszło, którzy się byli responsem zatrzymali, ale pospólstwo krzyknęło, że z radością czekamy cara Dmitra Iwanowicza, i zebrawszy się, wprzód Hodunow wszystkich pojmali, a nadto i samego Hodunowicza związawszy matkę i córkę jej, którego sami po kilku dni i matkę jego udawili. Tylko pana Oksinka na powitaniu 
została. I takeśmy już prosty szli do Moskwy. Przyszliśmy na św. Piotr ruski i do tego czasu w stolicy moskiewskiej mieszkamy, gdzie się zdrada w Moskwie pokazała nad carem, bo Szujscy poczęli odwodzić pospólstwo, powiadając to, iż to nieprawdziwy car, ale królewicz polski, iż chce wiarę naszę złamać, a luterską ustawić. Tak też i o zdrowiu nas wszystkich przemyśla, chcąc naród nasz wygubić. Do czego namówili 10 tysięcy człowieka synów bojarskich, gdzie nas mieli w nocy z gospodami palić i w ostatku zabijać. Co im Pan Bóg prędko odmieni umysły. Wziąwszy wiadomość naszy, dali znać carowi JM, który kazał był potracić, a potem darował gardłem, ale ich zesłano na Sibir do więzienia. O odprawie żołnierzów naszych nie wiem jako rychło nie ufając Moskwie, zaciagi dalsze z nimi czyni, i takiem zasłychnął, mówiąc: gdzie ich zapłata spełna dojdzie, prędko się im zachce do domu, na którym mnie siła należy. Żołnierze lepak [=zaś] tuszą sobie po koronacyi albo po ożenieniu prędkiej odprawy, lecz się musi przedłużyć, bo na JM pannę wojewodziankę sędomirską pewnie pojąć i po koronacyi posłać po nie.

Dat. [um] tego listu z samej Moskwy miasta stołecznego 24 Iulii Anno 1605.

\section{Marcin, Andrzej Piotr Stadniccy do Szymona Rudnickiego, biskupa warmińskiego ${ }^{1}$, z Moskwy, 8 lipca 1606}

Rps BCzart. 1628/IV, s. 349-350 (oryginał)

Jesteśmy tu na zatrzymaniu od cara teraźniejszego — proszą o przyczynę do króla o [wybawienie ich] wyswobodzenie. Gdyby król nie pozwolił wojewodzie sandomierskiemu wyjazdu z córką do Moskwy, „i nam by się nie schodziło zaciaggać, gdyżeśmy się przedtem nie ważyli onemu w dopomagać na wojny i insze rzeczy, dopiro za pozwoleniem JKM daliśmy się uwieść”, nie wziąwszy ani od p. wojewody, ani od cara, żadnych pieniędzy, ani od carowej „najmniejszego pieniądza, swym tylko kosztem odprawując, za co i wolność straciliśmy".

Ceduta: Przyjechaliśmy do miasta Moskwy w piątek, to jest 12 maja, jakie przyjmowanie było, iż mi nic do tego, nie piszę. Nieboszczyk ${ }^{2}$ wyjeżdżał, ale w monasterzu ${ }^{3}$ moskiewskim zamku czekał u swej matki, tam zsiadła carowa młoda ${ }^{4}$ sama tylko $z$ białymi głowami i z panem wojewodą. My do gospody poszli, którąśmy mieli i różnie od siebie, i daleko jeden od drugiego bardzośmy stali. Do carowej młodej nas nie puszczono. W sobotę $z$ wielką ceremoniją na majestacie siedzącego witaliśmy nieboszczyka, JM pan brat Marcin nieszczęśliwie od wszystkich onego witając, rzecz czynił. W niedzielę noc uczcił, to się tak wlekli ceremonije, aż do czwartku i odpra-

\footnotetext{
1 Marcin Stadnicki herbu Śreniawa (ok. 1552-1628), ochmistrz dworu carowej Maryny Mniszchówny, krcwny Mniszchów, późnicjszy (od 1609 r.) kasztelan sanocki, brat „Diabła” Stadnickicgo, starosty zygwulskicgo; Andrzej Piotr Stadnicki, brat Marcina, uczestnik Dymitriady, w nicwoli u Szujskicgo; Szymon Rudnicki (1552-1621), sckretarz wiclki koronny (1601), 4 paździcrnika 1604 roku instalowany na biskupstwo warmińskic, 6 marca 1605 roku konsekrowany przez nuncjusza papieskiego Claudio Rangonicgo.

${ }^{2} \mathrm{Tj}$. Dymitr I Samozwanicc, powszechnic uznawany za Juszkç (imic̨ zakonne Gregorij) Otrepiewa, zamordowany w wyniku spisku kniaziów Szujskich 27 maja 1606 roku w czasic uroczystości wesclnych.

${ }^{3}$ W jednym z klasztorów moskicwskich, gdzic przcbywała Maria Nagoj, w zakonic Marfa, żona Iwana IV Groźncgo, rzekoma matka Dymitra Samozwańca.

4 Maryna Mniszchówna, córka Jerzego Mniszcha, wojewody sandomicrskiego.
} 
wowali poselstwa przez JMci pana małogoskiego ${ }^{5}$. We czwartek koronowano carowę młodą, szlub potwierdzono ${ }^{6}$, to się zaś prowadziły rzeczy aż do dni kilku. Piszęć krótce, w sobotę rano bardzo, 27 maja, cara zabito, jako i kto, o tym trudnoć, ciało wynieśli, na gwałt uderzono, a myśmy dopiero poczęli się zbierać. Gmin wyrzuciwszy ciało cara zabitego, rzucili się na naszych, zabitych liczby nie piszę. Nie bronił się, poddał się p. Samuel Bal ${ }^{7}$ i zabit, wszystko porozszarpano. W inszym miejscu zabit pan Piotr Domaracki stary ${ }^{8}$, indziej pan Strzyżewski ${ }^{9}$. Pana Żebańskiego ${ }^{10}$ syn, ks. Pómaski z bratem ${ }^{11}$, pan Komorowski z Żywca ${ }^{12}$, pan chorąży przemyski ${ }^{13}$ poddał się, tego zabito, czeladzi moc wielka, wszytko pobrano, nagą snać z żoną zostawiwszy samego, kilkakroć zabić chciano. Żona nań padła i tak ratowała, którą potłukli. Na nas uderzyli, sami dwa z panem Marcinem byliśmy w jednym dworze, w swym stanowisku broniliśmy się, $z$ łaski Bożej żadnego nam nie ubito. Onych po trosze poległo. Potym działa na ostatku $z$ dwóch stron zatoczono. Pan Bóg się zmiłował, przybiegło dwu bojarów, jęli hamować, myśmy się radzi uhamowali, dopiero nam dali znać, iż sam car zginął, dopiero jęli dobywać od nas rzeczy książęcia Wiśniowieckiego ${ }^{14}$ kilka godzin i z dział bito, wszystko mu pobrano, bronił się dobrze, na ostatek w jednej izbie, aż też bojarowie przybiegli i hamowali. Pana posła, pana wojewodę sędomirskiego nie dobywali; pana starostę sanockiego ${ }^{15}$, ale panu wojewodzie czeladź stajenną wybito i konie pobrano; muzykę wybili. Dopiero do nas przyjechał kniaź Dymitr Szujski, brat dzisiejszego cara, upewniając nas o zdrowiu. Zatym ku wieczorowi przyjechał sam kniaź Wasyl Iwanowicz Szujski, którego teraz carem obrano, ten nas cieszył i z płaczem obłapiał, obiecując nam i zdrowie i wolny odjazd.

Zatym osadzili około nas strzelców stu i ci nas strzegą, z gospody nigdzie nas puścić nie chcą, do nas nikogo zacnego nie puszczają, aniż sami nie jeżdżą, nędznie nas i konie nasze chowają. I tak

5 Mikołaj Oleśnicki herbu Dębno (ok. 1558-1629), kasztelan małogoski od 1598 roku, od 1619 roku wojcwoda lubelski, w czasie „krwawych godów” wraz z Aleksandrem Gosiewskim poseł królewski na wescle Dymitra, internowany po zamachu Szujskich.

${ }^{6}$ Zawarty uprzednio per procura przez posła Dymitra, Afanasija Własicwa w dniu 22 listopada 1605 roku w Krakowic, w obccności króla, jego siostry, królcwny Anny i królewicza Władysława.

7 Samucl Bal herbu Gozdawa, z rodziny senatorskiej osiadłej w ziemi sanockicj, którego wspomnina Nicsiecki (t. 2, s. 50), a takżc Scbastian Petrycy z Pilzna w poetyckiej parafrazic Horatius Flaccus w trudach więzienia moskiewskiego (op. cit., s. 57).

8 Piotr Domaracki, względnie Domaradzki, zapewne brat Macicja, wymienioncgo u Borszy (zob. s. 96).

${ }^{9}$ Strzyżewski (Strzeżowski, Strzyżowski) herbu Gozdawa, z zicmi sanockicj, wspomniany przez Petrycego (ibidem).

10 Żebański - osoba nieznana, nie wymicnia go również Niesiecki.

11 Ks. Franciszek Pomaski, kanonik płocki, sckretarz królewski, kapelan carowcj Maryny, zamordowany został w czasie odprawiania mszy św:; jego brat był podkomorzym carowej

12 Jan Komorowski z Życa herbu Korczak, wspomina o nim Pctrycy (ibidem); jednakże Diariusz Wacława Dyamentowskiego (op. cit., s. 99), wspomina, iż w początkach kwictnia 1607 roku, za zgodą cara Szujskicgo miał być przydzielony do świty wojewody sandomicrskicgo Jerzego Mniszcha, zaś wg Chronografii albo dziejopisu żywieckiego (Żywicc 1987, s. 113) miał zginą́ Andrzcj Komorowski z Żywca. Wątpliwości tych nie rozjaśnia Pamiętnik Stanisława Niemojewskiego, wydany przez Alcksandra Hirschberga, Lwów 1899, s. 66, 74, 77, 86, 92, gdzic przy nazwisku nie podano imienia, stąd trudność w identyfikacji.

${ }^{13}$ Zygmunt Tarło herbu Topór, chorąży przemyski, później kasztelan sądecki, pochodził ze znakomitej rodziny o zainteresowaniach intelektualnych w czasach Zygmunta Augusta, wspomnianej przez Eukasza Górnickicgo w Dworzaninie... (s. 39, 174).

${ }^{14}$ Ks. Konstanty Wiśniowiecki, późnicjszy (od 1638 roku) wojewoda ruski, ziçć Jerzego Mniszcha, wojcwody sandomicrskiego.

${ }^{15}$ Stanisław Mniszech, starosta sanocki, syn wojewody, brat carowcj Maryny. 
nie bywszy na wojnie, więźniami jesteśmy. Aż do tego czasu nie wiemy, co się z nami dziać będzie. Do JMci pana prosiliśmy, aby nas puszczono, nie chca, i tak gdzie kto żyw, tam go trzymają, nigdzie nie wypuszczając. $Z$ inszych znacznych wielu pobito, o czym szyrzyć się nie chcę. Teraz już czeladź wysyłają i żołnierstwo już wysłali. Zdarz Boże, aby prosto ku granicy a zdrowo. Samych wiele pobito, o tym jednak nic.

Z Moskwy, die 8 Iunii Anno 1606.

WMci naszego miłościwego pana uprzejmi przyjaciele i słudzy: Marcin ze Żmigroda, Andrzej Piotr Stadniccy ręką swą. 